\title{
The Relevance of the Reading Process in the Context of Estonian Literary Criticism ${ }^{1}$
}

\author{
SUSANNA SOOSAAR
}

\begin{abstract}
The importance of the reading experience has been accepted in literary studies ever since the advent of reading-response theories in the 1970s-1980s. Several notable scholars have stressed that meaning is created through the interaction between reader and text, highlighting the significance of the reader. Even though the main principles of reader-response have become commonplace, for some time, reading theories remained relatively stagnant. In the 2000s, however, the topic of reading was rediscovered as new perspectives for examining the reading experience and the reader's relationship with the text were offered. These new theories shed new light on the figure of the reader and on the work that goes into the process of reading. While the question of the experience of reading has been under discussion in the Anglo-American context, it has never been widely discussed in Estonia. The purpose of this article is to give an overview of well-known reader-response theories that became popular in the 1970s. In addition, examples of a renewed interest in reader-response theories in recent decades are presented. Finally, the article will also examine how Estonian-language literary criticism has engaged with reader-response theories.
\end{abstract}

Keywords: reading; reader-response theories; Estonian literary criticism; interpretation

\section{What Happened to Reader-Response Theories?}

According to the French scholar Georges Poulet, it is reading that gives books their meaning. Before they are read, books are merely material objects, waiting to be opened and made into "a series of words, of images, of ideas which in their turn begin to exist” (Poulet 1969: 54). Reading theories that developed at the height of the theory boom in the 1960s and 1970s have greatly influenced the way the reading process is treated in literary criticism. In the middle of the $20^{\text {th }}$ century, literature departments became increasingly "hospitable for theoretical diversity," and "criticism as the discipline of analyzing the literary" became the

\footnotetext{
1 This work was supported by the Estonian Research Council grant PRG934.
} 
The Relevance of the Reading Process in the Context of Estonian Literary Criticism

norm (Gallagher 1997: 140, 142). One of the theoretical strands to emerge was reader-oriented criticism.

It is hard to pinpoint the origin of reading theories. Some consider the Constance School, headed by Hans Robert Jauss and his work on aesthetic response to be responsible for the lively discussions on reader-oriented criticism in the 1970s and 1980s. Others trace the research of the reading process to the works of I. A. Richards or Louise Rosenblatt, who worked with the topic already in the first half of the $20^{\text {th }}$ century. There are some who believe Roland Barthes's proclamations in his essay "The Death of the Author" (originally published in 1967) to be a catalyst for reorganizing the processes of literary criticism. Barthes (1977: 148) suggests that since "a text is made of multiple writings" that find their meaning locus in the reader, meaning ought to be liberated from the clutches of authoritative explanation, thus calling forth "the birth of the reader."

There are varied approaches to reader-oriented criticism. In his book Interpretive Conventions: The Reader in the Study of American Fiction, Steven Mailloux (1982: 23) proposed a schema that separates theorists according to the models they use for "critical exchange" to locate "each critic on a continuum of reader-oriented approaches." For example, Mailloux (1982: 22) believes that Norman Holland and David Bleich occupy the psychological model; Wolfgang Iser and Stanley Fish operate within the intersubjective model; and Jonathan Culler's and Stanley Fish's later work is rooted in the social model. While it can be claimed that "there is no unity among reader-oriented theorists and critics," there is a strong link between theorists who have taken the reader as the central figure in their literary criticism (Prince 2013: para. 7). Indeed, prioritizing the agency of the reader can already be heard in Barthes's invitation to place meaning-making on the shoulders of the reader as well as through the theories of succeeding reading theorists who believe in readers' freedom to develop their own interpretations of texts.

While reader-response theories were a popular topic in literary journals during the 1970s and 1980, they never acquired the same kind of discipleship some other literary theories enjoyed. Perhaps the voices of reading theorists were drowned out by more "aggressive movements," which, according to Catherine Gallagher (1997: 150) include "ethnic studies, gender studies, feminism, New Historicism, and deconstruction." Or, perhaps the reason lies within the "lessening of theoretical polemical fervor" that literary theories experienced in the 1990s and their absorption "into the mainstream" (Gallagher 1997: 150). Whatever the reason, reading theories were not at the forefront of literary criticism after the 1980s but their significance never waned either. 
Instead of becoming a structured methodology, reading studies branched out. During the 1990s (and until this day), reception studies - studies of actual readers or the texts of actual readers - became quite popular, as the responses of actual readers had hardly been researched previously. Reception studies have seen several important collections published - the most notable ones being Philip Goldstein's and James L. Machor's Reception Study: From Literary Theory to Cultural Studies (2001) and New Directions in American Reception Study (2008) - and seem to be discussed more widely than reader-response theories. However, the significance of early reader-response theories can also be perceived today. In her article, "The Reception of Reader-Response Theory," Patricia Harkin (2005: 413) explains that nowadays, "it's fair to say that readerresponse conceptions are simply assumed in virtually every aspect of our work," echoing Gallagher's remark about literary criticism in general becoming 'mainstream'. Instead of becoming a method of reading studies, reader-response became a concept accepted by most literary scholars. That interpretation is determined by each reader became a "theoretical commonplace" is something that no scholar denies (Harkin 2005: 414). However, this by no means indicates that reader-response theories are somehow dated. In the 2000s and 2010s, reading theories have been rediscovered in the Anglo-American context. Several scholars, such as Karin Littau (2006), Rita Felski (2008), and Paul Armstrong (2013) have once again taken up the concepts of reading theories and are offering new perspectives to the research of readers and reading.

However, in Estonian literary criticism, reading theories have remained relatively undiscussed. A paper giving an overview of reader-response theories might thus be helpful in encouraging discussion on this topic. While the principles of reading theories are probably accepted by Estonian literary scholars as well, there has never been a big discussion about the tenets of reader-response in Estonian literary journals. ${ }^{2}$ Therefore, the purpose of this article is to examine the influence (or the lack of) of reader-response theories in the Estonian context. ${ }^{3}$ The article will first introduce some of the most important theories of reader-response developed in the 1970s-1980s (with a

2 For the purposes of this article, I searched for academic discussions on reading theories in two literary journals that are considered as influential in the Estonian-speaking academia, Keel ja Kirjandus and Akadeemia. The search yielded only a small number of results. Furthermore, this article will not present all of them but will focus on a select few.

3 It should be mentioned, however, that while studies using reader-response theories are few in number, reception studies have proven to be quite popular in Estonian literary criticism. Nevertheless, as this article focuses on reader-response theories, I will not elaborate on reception studies in the Estonian context. 
The Relevance of the Reading Process in the Context of Estonian Literary Criticism

focus on the theories of Stanley Fish and Wolfgang Iser). Then, the rediscovery of reading theories in the Anglo-American context will be discussed. Finally, I will examine how Estonian literary criticism has participated in discussions concerning the reading experience. This is especially important as there does not seem to be any studies focusing on reader-response theories in the Estonian context written in English.

\section{Uses for Reading Theories - Then and Now}

According to Harkin (2005: 415), the interactive nature of reader-response theories makes them 'easily understood' and highly 'teachable'. This is reiterated by Paul Armstrong (2011: 93), who explains that one of the reasons "for the neglect of reading in current critical discussion [...] is the widespread assumption that an analysis of reading is necessarily ahistorical and universalizing." In contrast, Armstrong (2011: 102, 104) proposes that we rethink "the experience of reading as a doubled performative interaction" meaning that reading should be considered an encounter between the text and the reader where both parties have the potential to shape one another - and 'embrace' the pedagogical inclinations that reading theories offer.

Armstrong's suggestions above have mostly grown out of the theories of Wolfgang Iser. In his book The Act of Reading, Iser (1978b: 66) explains that "the process of reading is basically a kind of dyadic interaction." The text contains a number of possibilities for interpretation and the reader can choose among the options presented by the text. However, once a selection is made, it starts to modify further associations - readers themselves are constantly producing the text through what Iser calls 'gestalt-forming'. Iser also suggests that while the text offers some options for interpretation in the reading process, it never finalizes the choices. Instead, through the constant interaction between the reader and the text, the reader becomes responsible for the final interpretation of the text, making the reader a creator of the text as much as the author is (Iser 1978b: 119, 126-127).

Another important aspect explored by Iser is the set of expectations that the reader imposes on the text. According to Iser, (1978b: 128) "[f]rom the very beginning, each text arouses particular expectations, proceeds then to change these, or sometimes fulfills them at a time when we have long since ceased to envisage their fulfillment and have already lost sight of them altogether." The expectations produced by the text guide the reading process and determine the reading experience. In fact, part of the reading enjoyment comes from the expectations incited by the text. As readers make predictions and look forward to revelations about to be uncovered in the text, their expectations may be 
"shattered, altered, surpassed, or deceived, so that the reader is confronted with something unexpected which necessitates a readjustment" (Iser 1978a: 58). The realization or frustration of the expectations that the reader has set for the text vastly influences their further assessment of the text.

It is imagination that activates the reader's expectations and meaningcreation. The imagination of readers is, in turn, activated by what Iser calls 'blanks and gaps' in the text. These empty spaces give readers "the opportunity to picture things," and that "without the elements of indeterminacy, the gaps in the text, we should not be able to use our imagination" (Iser 1978a: 283). The gaps are filled by the imagination of the reader to make the text coherent and the story's progress consistent. In addition, through his or her imagination, the reader is able to incorporate a fictional situation into their store of experiences. If the text activates the readers' imagination and the readers fulfill their role of constructing the imaginary object, they will be able to "transcend the limitations of their own real-life situation" (Iser 1978b: 79). The act of imagination, then, is necessary for a cohesive reading experience as well as for the world of the text to become available to the reader.

While the term 'implied reader' originates from the writings of Wayne Booth, it is now mostly associated with Iser. The first important aspect of the implied reader is that this reader is hypothetical. The implied reader is not a person but rather a "model to describe the effects of the literary text" (Iser 1978b: 38). The implied reader is present in the text and is part of the text while the flesh-and-blood reader participates in the text through the implied reader. Iser (1978b: 38) defines the implied reader as "a transcendental model which makes it possible for the structured effects of literary texts to be described." Thus, the implied reader creates a space for the projection of the effects of the text, a space that the living readers may inhabit while retaining their background selves (Iser 1978b: 27, 37). The background of experience that the living reader maintains while being settled in the role of the implied reader allows accounting for all the different interpretations that living readers hold while reading the same text (Iser 1978b: 35). Simply put, the implied reader offers a point of view to the living reader for the interpretation of the text.

There is a lot of criticism of the concept of the implied reader. Nelles (1993: 30) observes that although the name of Iser's book, The Implied Reader, suggests that an implied reader is its focus, the term itself is only mentioned once within the book. Steven Mailloux (1982: 203) believes that the implied reader is "the reader that the critic interprets the text as requiring," that is, the implied reader is Iser's personal interpretation of the reader implied in the text. The effects of the text that are revealed through the implied reader are, instead, interpretations of the text in isolation (Mailloux 1982: 49). According to Fish 
The Relevance of the Reading Process in the Context of Estonian Literary Criticism

(1981: 12), Iser's theory is "nothing more than a loosely constructed network of pasted-together contradictions.” Fish's review of Iser does not really offer any solutions to the problematic aspects present in Iser's writings but attacks Iser because he is "influential without being controversial" (Fish 1981: 2). Iser is mostly criticized for not seeing that the interpretations of the reader are "the products of an interpretive strategy that demands them" - this being one of the main assumptions made by Fish himself in his later work (Fish 1981: 7).

In his earlier work, much like Iser, Stanley Fish tried to develop a concept of the reader - in his case the informed reader. According to Fish (1980: 7), it is through this reader that the meaning of the text is manifested, as the reader has a "central role in the production of meaning." In the article, "Literature in the Reader: Affective Stylistics," Fish (1970: 145) describes the informed reader as "a construct, an ideal or idealized reader," who is "sufficiently experienced as a reader to have internalized the properties of literary discourses." Furthermore, the informed reader is competent and mature, a reader who is experienced "as a producer and comprehender" (Fish 1970: 45). The informed reader is supposed to turn away from the evaluation of the text and instead face "toward description" (Fish 1970: 146). As Fish's reader concept is rather abstract, it is hard to make comparisons between Iser's implied reader and Fish's informed reader. Perhaps Steven Mailloux (1983: 203) explained it best when he said that Fish's reader "is merely an abstracted version of the "implied reader." He is not a reader of a specific text but one implied by all literary texts; or put another way, he is a hypothetical reader with the general ability to comprehend literature."

While Fish (1970: 146-147) mentions that the concept of the informed reader is an essential tool for analyzing the text, he does not describe the roles of the informed reader nor does he offer methodical instruction on how to use this tool in literary analysis. At some point during the 1970s, Fish stopped developing the concept of the informed reader and instead directed his focus on the idea of interpretive communities that determine the shape of individual readings. In his Is There a Text in Class: The Authority of Interpretive Communities (1980), Fish explains that the reader's interpretations are preceded by interpretive strategies decided by the collective mind of the reader community to which the reader belongs.

Within the scope of the theory of interpretive communities, the text's meaning is predetermined before the reading process. Interpretive communities shape the entire cultural output of their community. Writers write according to the interpretive strategies of the interpretive community that they are part of and so do the readers. According to Fish (1980: 327), interpretive communities “make texts." However, Fish's updated focus on meanings made by interpretive communities has become a source of irritation for Fish's critics 
who presume that this signifies the removal of text as a source of interpretation and meaning, resulting in the text's disappearance (Mailloux 1982: 21, Littau 2006: 113-114 - based on Fish 1980: 172-173).

In the 1970s and throughout the 1980s, scholars, such as Seymour Chatman, Stephen Mailloux, David Bleich, Norman Holland, and Jonathan Culler, developed their own theories of reading. However, in the 1990s, the discussions concerning reading and readers became less pronounced as the debates in literary journals moved on to other topics. Iser continued writing about reading throughout the 1990s and his latest work was published in English as late as 2006. Fish, in turn, went on to tackle other topics after the publication of the collection Is There a Text in Class. However, the conversation around reading theories never died out. In the 2000s, the next generation of scholars took up the topic of reading again, even though, in the words of Paul Armstrong (2011: 89) the "return of reading is a rediscovery of something that never really disappeared."

New directions in reading theories have started to emphasize the need to relearn and review our knowledge of reader-response studies. In recent studies into the reading experience, scholars have moved in the direction of researching 'the material' and 'the bodily', that which affects not only the mind but the body as well, in one way or another. In her book Books, Bodies and Bibliomania (2006), Karin Littau discusses the materiality of books, started by Georges Poulet. Littau agrees that books are material objects but not simply material objects. Instead, Littau believes books to be physical objects that affect physical beings. Diverging from the path trodden by Iser and Fish, who only focus on the mental activities triggered by reading, Littau turns her attention to the visible effects texts have on readers - the bodily reactions, emotions, and feelings. She believes that these effects should be studied more thoroughly as reading is an affective experience producing actual "sensory stimulation" (Littau 2006: 41). Reading then, while usually conceived as an experience conducted by "a disembodied mind", should take into account the different physical responses that it produces: laughter, tears, a tingling spine, a racing pulse, "inflamed passions", as well as "irrational terror" (Littau 2006: 5, 10).

Margaret Hughes also, in her article "The Emotional Education of the Reader" (2013), argues that readers are often emotionally involved in the plot and characters of fictional texts and thus reading may help readers participate in experiences never encountered in real life. Hughes (2013:16) argues that it is possible for readers to feel emotions along with the characters in the fictional situations they are reading about. The act of reading can make such a strong impression on the reader that the reader feels real emotions in their very real world. This argument repeats the position of Georges Poulet (1969: 57) and his 
The Relevance of the Reading Process in the Context of Estonian Literary Criticism

belief that during the reading process "with the total commitment required of any reader, my comprehension becomes intuitive and any feeling proposed to me is immediately assumed by me."

Similarly, Rita Felski (2008: 54) acknowledges that reading produces "intense and enigmatic pleasure" and formulates four categories that influence readers' enjoyment of literature: recognition, enchantment, knowledge, and shock. The categories of enchantment and shock are especially relevant in illustrating the bodily responses of readers. The category of enchantment exposes readers' susceptibility to letting the text 'take over': "you feel oblivious to your surroundings, your past, your everyday life; you exist only in the present and the numinous presence of a text" (Felski 2008: 55). Shock, in turn, "names a reaction to what is startling, painful, even horrifying" (Felski 2008: 105). Through the category of shock, literary texts produce sensations that may leave the reader speechless, disgusted, fearful, or even numb, it is an "aesthetic that assaults our psyches and assails our vulnerabilities" (Felski 2008: 110, 112, 131). Felski's view of literary texts, then, shows that the reading experience is one of full immersion. Her ideas contain the same shadow of Poulet's phenomenology that marked the texts of Hughes and Littau. The sentiment of a fully immersive reading experience can, indeed, be read from Poulet's (1969: 54) conviction that reading enables the reader to step inside the text, resulting in an experience where "there is no longer either outside or inside."

The affective turn in reading studies strongly resonates with Poulet's phenomenological position as well as with Iser's ideas about the reading situation affecting readers through their own imagination. However, it is not the only direction that reader-response research has moved on to. Paul Armstrong, for example, has worked with reading theories since the 1980s. His 2005 book Play and the Politics of Reading heavily draws on Iser's research, especially Iser's 1993 book The Fictive and the Imaginary. However, Armstrong's 2013 book How Literature Plays with the Brain shows that reading studies are becoming more and more interdisciplinary. In the book, Armstrong (2013: xiii) studies the connections between aesthetic experiences and the "processes of interpretation, cognition and meaning creation in the mind," using phenomenological readerresponse theories, hermeneutics, aesthetics, and neurobiology.

A brief history of literary criticism suggests that it could be categorized by certain focal points that attribute importance to the author, the text, and finally, the reader. This triadic separation of aspects of literary works has created an analytical rhythm that characterizes the history of literary criticism. The constant multiplication of theories has ensured that each element will be found to be of use at some point. The 'Author' enjoyed a long period of attention until the middle of the $20^{\text {th }}$ century when New Criticism shifted the focus on the 
text. Finally, at the end of the 1960s, the reader received its turn in the spotlight. As was previously mentioned, Barthes's text on the death of the 'Author' is widely regarded as the text that started the ascent of the reader. However, when it comes to the concept of the reader, was the reader ever born?

Barthes (1977: 148, his emphasis) says that "the reader is without history, biography, psychology; he is simply someone who holds together in a single field all the traces by which the written text is constituted.” This statement highlights that Barthes may have been thinking about a conceptual reader and not about a real, flesh-and-blood reader. The same can be said about the theoretical readers of Iser and Fish, who practiced textual analysis through a reader figure. While seemingly operating on a more material level, even the affective turn in reader theories seems to be dealing with a theoretical reader and not a real reader. The concept of the reader is clearly a textual construction - an interpretation of the creators of the theory who see their readers as universal concepts. However, it should be noted that, when analyzed, any living flesh-and-blood reader also becomes a construction (Mailloux 1982: 204). Even in reception studies, where real readers are the objects of research and where readers' responses (mostly in written, sometimes in oral form) to fictional narratives are analyzed (as opposed to fictional narratives themselves being analyzed), the readers' responses studied are "the result of a critical interpretation” (Mailloux 1982: 205). Has the reader, then, ever been central in literary theory?

It seems inevitable that the reader is reduced to a tool that enables us to analyze literature. This inevitability may come from the incompatible foundations reader-response theories were set upon. On the one hand, phenomenological research into the experience of reading has been fueling reading theories ever since Poulet first published his contemplation on reading and has continued in the works of scholars working with affect theory today. On the other hand, the formalist grasp on literary analysis seems to be inescapable when looking at the literary analyses of leading reading theorists. The theories, also, have lived different lives in different literary theoretical cultures, an aspect which will be further studied below, with a focus on the academic discussion on reading in the Estonian context.

\section{The Estonian Context}

In the Anglo-American academia, the conversation on reading theories has been irregular, to say the least. However, even less has been said on the reader in Estonian literary criticism. At the beginning of the 1990s, several translations were published in Estonian literary journals. For example, Iser's article "The 
Reading Process: A Phenomenological Approach" was translated into Estonian and published in the journal Akadeemia and Fish's "Interpreting Variorum" was published in translation in the same journal in 1991. In addition, some articles by Finnish scholars on reading theories were also translated into Estonian: Claus Zilliacus's article "Om läsarens betydelse för det lästa” was published in translation in Akadeemia in 1993 and Jan Blomstedt's essay about the readers' revolution appeared in Vikerkaar in 1990. However, there does not seem to be a lot of dialogue between these translated articles and Estonian literary criticism, or, at least, not in the journals studied for this article.

Original articles published in Estonian academic and literary journals about reading theories are also few. One of the earliest, published in 1991 by Endla Köst in the literary journal Keel ja Kirjandus, is perhaps the most interesting one. In the article titled "Adressaadist ja virtuaalsest lugejast ilukirjanduslikus tekstis" ("Addressee and Virtual Reader in Fiction"), Köst includes an overview of the history of researching the reading process, which includes the theories of German, American, French, and Russian literary scholars. In addition to scholars, such as Jauss and Iser, Soviet-era scholars, some well-known (such as Bakhtin) and some that are rarely mentioned in Anglo-American studies of reader-response (such as K. Goranov, M. Glowinski, E. Czaplejewicz) are cited by Köst. However, Köst's main focus is on the experience of writers and she makes conclusions based on what authors themselves have written about their intended audiences. Through this study of intended audiences, Köst develops the idea that every work of fiction has what she calls a virtual reader present in the text. That is, a reader is present in the text before the reading process has begun - a verdict not unlike Iser's idea of the implied reader. Köst has also published a book in 1986, titled Loomine ja lugemine (Creation and Reading), where she interviews Estonian writers about their writings and their reading interests. The introduction of the book focuses on studies of reading by Russian literary theorists and is similar to the 1991 article by Köst.

The most influential studies on reading in Estonia, however, were written by Jaanus Vaiksoo in the mid-90s. His article published at the beginning of 1994 in the journal Keel ja Kirjandus focuses on the idea of reading models. The article gives an overview of the beginnings of reader-response theory where his main emphasis is on Jauss's contribution, and where Iser also receives a mention. However, Vaiksoo's approach is indebted to a German scholar Detlef Krumme and his 1981 dissertation on reading models. The theory of reading models reiterates some already well-established truths within reader-response theories, such as the reader's active involvement in the creation of meaning, the reader's expectations shaping the content of the text, and the belief that texts are layered and thus offer several options for interpretation. However, it is not 
exactly clear what the concept of reading models has to offer in addition to these ideas. Based on how it is treated in the article, it seems that the concept of reading models is simply a way of speaking about interpretations. The article explains that "the content of a book is dependent on the number of readers; every reader finds a specific level of meaning that is determined by their previous knowledge of the book and on their social environment" and that readers are mostly interested in personal meanings triggered by the reading (Vaiksoo, 1994a: 171, 173 my translation). Thus, reading models follow each reader's personal interpretations and are contingent on the reader's interests and background.

Vaiksoo also explains that reading models may be distinguished by periods and generations - each generation has a collective model of reading and that there exists a general interpretation of texts that is determined by the understandings prevalent during a certain period. This idea is quite similar to Fish's interpretive communities, according to which the reader's understanding of a text is a product of a community that determines the principal strategies for writing, reading, and interpretation. However, when comparing Fish's interpretive communities and Krumme's collective models of reading, Fish's ideas seem to be more elaborate. The same can be said when comparing the reader's role in Krumme's theory and in Iser's theory. Thus, based on Vaiksoo's description of Krumme's reading models, many elements seem to be recycled from the reading theories that were already thoroughly discussed in the English-speaking academia by the time Krumme's dissertation was published. Since the foundational aspects of reader-response theories had been established before Krumme, the functionality of Krumme's reading models is not clear.

However, in another article Vaiksoo demonstrates the use of Krumme's reading models in literary analysis. In an article that appeared in Keel ja Kirjandus five months after the first article on reading models was published, Vaiksoo discusses different reading models that have been applied to an Estonian novel, Toomas Nipernaadi (1928). In this article, the author follows the reception of the novel and analyzes critics' ways of reading the novel. The analysis shows that the novel can be interpreted according to several reading models, such as the autobiographical, the mythological, the folkloristic, the Bildungsroman, the satirical, and the romantic reading model. While Vaiksoo does mention that these reading models are based on critics' interpretations, there is no further explanation of reading models in this article. Questions, such as, whether the reading models are something universal, how such reading models could be further used, or whether other reading models could be used in the interpretation of the novel remain unanswered. Vaiksoo briefly mentions Krumme and the collective model of reading but does not elaborate 
The Relevance of the Reading Process in the Context of Estonian Literary Criticism

on the influence of Krumme's theory in this article. One can only assume that Vaiksoo is using the reading model theory introduced in the previous article. It is rather interesting that, while the first article by Vaiksoo can be considered as a study of one particular reader-response theory, the second article falls into the branch of reception studies. Of course, one could make the argument that since reception studies developed out of reader-response studies, a mix-up in methods might be understandable. However, such a big theoretical shift is unusual in other significant studies of reading.

Vaiksoo continues the discussion on reading theories and reading in later years as well. For example, in a 1998 article published in Keel ja Kirjandus, titled "Võitlevad lugemismudelid" (Battling Reading Models), Vaiksoo reviews a doctoral dissertation defended at the University of Tampere. The dissertation seems to support Vaiksoo's attempt to bring more clarity to the concept of reading models, with the conclusion that they are dependent on communities of readers. This discussion again echoes Stanley Fish's work on interpretive communities and Vaiksoo's own discussion of Krumme's vision of dominant worldviews of certain periods shaping the reader's interpretations. Deviating from the topic of reading theories but remaining within the discussion on readers, Vaiksoo publishes another article in Keel ja Kirjandus in 2009, where he finds it problematic that in Estonian, lay readers are often called simple or ordinary readers. He argues that in Estonian, using a more neutral term, 'hobby reader' ('harrastuslugeja') or simply saying 'reader' would be more appropriate when describing readers who like to read and whose expectations of texts are just as significant as those of professional readers. ${ }^{4}$

Vaiksoo's articles provide a theoretical basis for Johanna Ross's $\mathrm{PhD}$ dissertation defended in the University of Tartu in 2018. Ross's work focuses on the different reading models in the novels of Soviet Estonian women writers and is perhaps the most significant work concerning the study of different readings in Estonian literary studies. Her work shows that reading (and writing) in order to resist the prevailing social order was rather common and that informed readers' ${ }^{\text {s }}$ were able to read between the lines and thus literature written in Estonia during the Soviet period was often interpreted to oppose the regime's

4 The latter topic was also discussed by Eric Livingston in his 2006 article "The Textuality of Pleasure." Just like Vaiksoo, Livingston is displeased that literary critics are mostly concerned with how they themselves read, yet the lay readers' work of reading is rarely recognized. This shows that perhaps the ideas occupying the minds of Estonian scholars and the ones working within the English-speaking academia, are not so different after all.

5 Ross $(2018: 194,269,295)$ makes use of the term 'informed reader' without mentioning any theoretical frameworks associated with the concept. 
SOOSAAR

official ideology. While the theories of Iser, Jauss, Eco and even Felski are mentioned in the theoretical part of the dissertation, Ross seems to be more concerned with analyzing the works of Soviet Estonian women writers and their critical reception than building a theoretical argument in the field of reader-response. In the theory section of the dissertation, Ross grounds her theory in Vaiksoo's articles on Krumme and references Krumme's own work as well. However, she does not copy Vaiksoo's methods from the second 1994 article, nor does she keep the terminology used by Krumme and Vaiksoo. Instead, Ross adapts their work for her own purposes, with one of the most significant changes being the substitution of the concept of 'reading models' for her own term, 'reading modes'. It is interesting that the only sources written in Estonian on reading theories used in the dissertation are Vaiksoo's articles. Unfortunately, the reason seems to be that the discussion on reading theories in Estonia has not received the attention it deserves; and therefore, the theoretical discussions in Estonian from which to choose were few in number. However, the fact that the dissertation was defended only recently shows that perhaps the topic of reading is only now starting to become more prevalent in Estonian literary criticism.

We can only speculate on the reasons why reading theories are not widely discussed in Estonia. One of the reasons might be due to the social order that prevailed during the period when the Western world turned their eyes upon the reader. Since Estonia was part of the Soviet Union when reading theories became popular, Estonian literary scholars might not have had the opportunity to comment on Western trends. In his article, Köst (1991: 402) comments that Soviet-era scholars did catch the latest literary movement directed at the reader in the 1960s. However, in the 1970s, the movement became unfavorable as the trend might have resulted in 'inappropriate conclusions' for the social situation (Köst 1991: 402). Thus, it was nearly impossible for Estonian scholars to argue about the different meanings of literary works as disclosing different reader interpretations could have even been dangerous. However, tracing opposing interpretations is not impossible anymore, as Johanna Ross's work demonstrates. Choosing to concentrate on the national-oppositional and feminist reading modes, Ross shows how different modes of reading can be applied in the interpretation of Soviet-era literary works in their original context as well as in research today.

Another reason for the lack of thorough discussion on reading theories might be due to the complex ways ideas circulate. While certain theories prosper through translation, others are forgotten. During the 1990s, a lot of theories were translated into Estonian from French and English. However, it is hardly possible to dictate an even distribution of ideas. Those theories that 
thrive in translation are reproduced through local scholars while securing a strong foothold. The unlucky theories, reader-response among them, are given minimal consideration on the sidelines. Some discussions were simply never initiated.

While there may be many more reasons why reading discussions never reached the Estonian-speaking academia on paper, there is still time to become involved in the field of reading studies and contribute to it. Theories of reading have not been finished and the problems surrounding reader-oriented criticism are not solved; the commotion raised about reading in English in the 1970s only set up a foundation for the study of reading. There are still many loose ends when it comes to theories of reading and contemporary theories of literary criticism as well as other disciplines can make valuable contributions to the study of reading. Critical studies on reading and readers will help us understand the processes of the reading experience.

In a short piece published in the journal Keel ja Kirjandus in 2006, Rein Veidemann expresses his concern over Estonian readers and their lack of interest in the future of Estonian literature. The article makes the argument that we are what we read. Readers are not only creators of texts, but texts are what create readers as well. However, the lack of active readers of Estonian literature may lead to the end of a healthy development of literary texts, which in turn, leads to the end of an informed, active and devoted readership. The author explains that the only way to stop the process of the perishing of the readership is to master the art of reading. Perhaps reading theories can also be of assistance in this aspect. Reading becomes relevant again if we talk about it. After all, this very article may be considered as a way of reading, a reception of Estonian-language articles on reading.

\author{
Susanna Soosaar \\ susanna.soosaar@ut.ee \\ College of Foreign Languages and Cultures \\ University of Tartu \\ Lossi 3 \\ 51003 Tartu \\ ESTONIA
}


SOOSAAR

\section{References}

Armstrong, P. 2005. Play and the Politics of Reading: The Social Uses of Modernist Form. Ithaca: Cornell University Press.

Armstrong, P. 2011. In Defense of Reading: Or, Why Reading Still Matters in a Contextualist Age. New Literary History, 42(1), 87-113. https://doi.org/10.1353/ nlh.2011.0001

Armstrong, P. 2013. How Literature Plays with the Brain: The Neuroscience of Reading and Art. Baltimore: The Johns Hopkins University Press.

Barthes, R. 1977. Image, Music, Text. Trans. by Stephen Heath. London: Fontana Press.

Blomstedt, J. 1990. Lugejate revolutsioon. Vikerkaar, 12, 51-68.

Felski, R. 2008. Uses of Literature. Oxford: Blackwell Pub.

Fish, S. 1970. Literature in the Reader: Affective Stylistics. New Literary History, 2(1), 123-162. https://doi.org/10.2307/468593

Fish, S. 1981. Review: Why No One's Afraid of Wolfgang Iser. Diacritics, 11(1), 2-13. https://doi.org/10.2307/464889

Fish, S. 1991. Variorum' it tõlgendamas. Akadeemia, 3(3), 509-539.

Fish, S. 2000. Is There a Text in This Class? The Authority of Interpretive Communities. Cambridge: Harvard University Press.

Gallagher, C. 1997. The History of Literary Criticism. Daedalus, 126(1), 133-153.

Goldstein, P. and J. L. Machor. 2008. New Directions in American Reception Study. Oxford: Oxford University Press.

Harkin, P. 2005. The Reception of Reader-Response Theory. College Composition and Communication, 56(3), 410-425.

Hughes, M. 2013. The Emotional Education of the Reader: A Progression through Works and Time. The Journal of Aesthetic Education, 47(4), 14-26. https://doi. org/10.5406/jaesteduc.47.4.0014

Iser, W. 1990. Lugemine: Fenomenoloogiline lähenemisviis. Akadeemia, 2(10), 20902117.

Iser, W. 1978a. The Act of Reading: A Theory of Aesthetic Response. Baltimore: John Hopkins University Press.

Iser, W. 1978b. The Implied Reader: Patterns of Communication in Prose Fiction from Bunyan to Beckett. Baltimore: Johns Hopkins University Press.

Köst, E. 1986. Loomine ja lugemine. Tallinn: Eesti Raamat.

Köst, E. 1991. Adressaadist ja virtuaalsest lugejast ilukirjanduslikus tekstis. Keel ja Kirjandus, 7, 402-407.

Littau, K. 2006. Theories of Reading: Books, Bodies, and Bibliomania. Cambridge: Polity Press.

Machor, J. L and P. Goldstein. 2001. Reception Study: From Literary Theory to Cultural Studies. London: Routledge.

Mailloux, S. 1982. Interpretive Conventions: The Reader in the Study of American Fiction. Ithaca: Cornell University Press.

Nelles, W. 1993. Historical and Implied Authors and Readers. Comparative Literature, 45(1), 22-46. https://doi.org/10.2307/1771304 
The Relevance of the Reading Process in the Context of Estonian Literary Criticism

Poulet, G. 1969. Phenomenology of Reading. New Literary History, 1(1), 53-68. https://doi.org/10.2307/468372

Prince, Gerald. 2013. Reader. - https://www.lhn.uni-hamburg.de/node/52.html (27.01.2020)

Ross, J. 2018. Aira Kaalust Mari Saadini. Nõukogude eesti naisarenguromaan ja selle lugemisviisid. Tartu: Tartu Ülikooli Kirjastus.

Vaiksoo, J. 1994a. Lugeja ja lugemismudelid. Keel ja Kirjandus, 3, 164-173.

Vaiksoo, J. 1994b. August Gailiti romaani ‘Toomas Nipernaadi’ lugemismudelid. Keel ja Kirjandus, 8, 460-475.

Vaiksoo, J. 1998. Võitlevad lugemismudelid. Keel ja Kirjandus, 4, 279-281.

Vaiksoo, J. 2009. Tavalugeja ja lihtlugeja? Keel ja Kirjandus, 5, 377-379.

Veidemann, R. 2006. Lugemise talumatu kergus. Keel ja Kirjandus, 7, 582-585.

Zilliacus, C. 1993. Lugeja tähendusest loetule. Akadeemia, 5(9), 1883-1891. 